\title{
EVALUACIÓN DE DAÑO POR AVES EN CULTIVARES DE SORGO (Sorghum bicolor) EN LAS BREÑAS, PROVINCIA DEL CHACO
}

\author{
CAsuso, M. V. ${ }^{1 ;}$ TARRAGÓ, J. R. ${ }^{1,2}$; JiMÉnEZ, J. O. ${ }^{1 ;}$ \\ Dardanelli, S. ${ }^{3}$ \& Pérez, G. A. ${ }^{1}$
}

\begin{abstract}
RESUMEN
El objetivo del presente trabajo fue evaluar las pérdidas de rendimiento ocasionadas por aves en microparcelas con distintos híbridos de sorgo. Se llevaron a cabo experimentos en los años

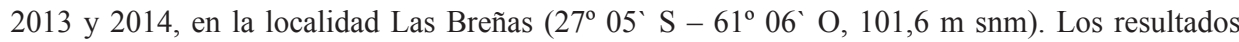
obtenidos demostraron que el ensayo del año 2013 registró en general un mayor daño por aves en comparación la experiencia del siguiente año, siendo en todos los casos mayores los daños por aves en los híbridos sin taninos. En el presente estudio la mayor permanencia de los materiales en el campo estaría influyendo en las pérdidas de granos ocasionadas por aves, lo que se vio reflejado en las mayores pérdidas registradas en los materiales de ciclo corto con respecto a los de ciclo intermedio, intermedio-largo y largo que estuvieron menos tiempo con granos en el campo ya que la cosecha se realizó en una sola operación cuando maduro el hibrido de mayor longitud.

Palabras claves: daño; aves; Sorghum bicolor; microparcelas.
\end{abstract}

\begin{abstract}
Damage assessment of brids in sorghum hybrid (Sorghum bicolor) in Las Breñas province of Chaco.

Experiments were conducted in 2013 (A) and 2014 (B) in Las Breñas $\left(27^{\circ} 05^{`} \mathrm{~S}-61^{\circ} 06^{`} \mathrm{O}, 101.6 \mathrm{~m}\right.$ $\mathrm{snm}$ ) to estimate yield losses caused by birds in microparcelas with different varieties of sorghum. In 2013 greater damage by birds was registered compared to 2014. In both years damage by birds was more relevant in sorghum varieties without tannin. In the present study the greater permanence of the materials in the field would influence the grain losses caused by birds, which was reflected in major losses in the short course materials regarding intermediate cycle-intermediate long and spent less time longer than grain in the field as the hybrid crop longest performed in a single operation when mature. Key words: damage; birds; Sorghum bicolor; microparcelas.
\end{abstract}

1.- EEA INTA Las Breñas, Chaco. (3722) Ruta 89, Km 227. casuso.violeta@inta.gob.ar

2.- Cátedra de Terapéutica Vegetal. Facultad de Ciencias Agrarias Universidad Nacional del Nordeste

3.- EEA INTA Paraná, provincia de Entre Ríos.

Manuscrito recibido el 24 de junio de 2015 y aceptado para su publicación el 16 de septiembre de 2015. 